Article

\title{
Synthesis and Characterization of
}

$\mathrm{Ag}-\mathrm{Ag}_{2} \mathrm{O} / \mathrm{TiO}_{2} @$ polypyrrole Heterojunction for Enhanced Photocatalytic Degradation of Methylene Blue

\author{
Rajeev Kumar ${ }^{1}$, Reda M. El-Shishtawy ${ }^{2,3}$ and Mohamed A. Barakat 1,4,* \\ 1 Department of Environmental Sciences, Faculty of Meteorology, Environment, and Arid Land Agriculture, \\ King Abdulaziz University, Jeddah 21589, Saudi Arabia; olifiaraju@gmail.com \\ 2 Chemistry Department, Faculty of Science, King Abdulaziz University, P.O. Box 80203, Jeddah, Saudi Arabia; \\ elshishtawy@hotmail.com \\ 3 Dyeing, Printing and Textile Auxiliaries Department, Textile Research Division, National Research Center, \\ Dokki, Giza 12311, Egypt \\ 4 Central Metallurgical R \& D Institute, Helwan 11421, Cairo, Egypt \\ * Correspondence: mabarakat@gmail.com; Tel.: +966-2-640-0000 (ext. 64821); Fax: +966-2-695-2364
}

Academic Editor: Dionysios (Dion) D. Dionysiou

Received: 30 March 2016; Accepted: 17 May 2016; Published: 25 May 2016

\begin{abstract}
Hybrid multi-functional nanomaterials comprising two or more disparate materials have become a powerful approach to obtain advanced materials for environmental remediation applications. In this work, an $\mathrm{Ag}-\mathrm{Ag}_{2} \mathrm{O} / \mathrm{TiO}_{2} @$ polypyrrole $\left(\mathrm{Ag} / \mathrm{TiO}_{2} @ \mathrm{PPy}\right)$ heterojunction has been synthesized by assembling a self-stabilized $\mathrm{Ag}-\mathrm{Ag}_{2} \mathrm{O}$ ( $p$ type) semiconductor (denoted as $\mathrm{Ag}$ ) and polypyrrole ( $\pi$-conjugated polymer) on the surface of rutile $\mathrm{TiO}_{2}$ ( $n$ type). $\mathrm{Ag} / \mathrm{TiO}_{2} @ \mathrm{PPy}$ was synthesized through simultaneous oxidation of pyrrole monomers and reduction of $\mathrm{AgNO}_{3}$ in an aqueous solution containing well-dispersed $\mathrm{TiO}_{2}$ particles. Thus synthesized $\mathrm{Ag} / \mathrm{TiO} \mathrm{OPPy}_{2}$ was characterized using X-ray diffraction (XRD), X-ray photoelectron spectroscopy (XPS), field emission scanning electron microscopy (FE-SEM), transmission electron microscopy (TEM), and UV-Vis diffuse reflectance spectroscopy (UV-vis DSR). The photocatalytic activity of synthesized heterojunction was investigated for the decomposition of methylene blue (MB) dye under UV and visible light irradiation. The results revealed that $\pi$-conjugated $p-n$ heterojunction formed in the case of $\mathrm{Ag} / \mathrm{TiO}_{2} @ P P y$ significantly enhanced the photodecomposition of MB compared to the $p$ - $n$ type $\mathrm{Ag} / \mathrm{TiO}_{2}$ and $\mathrm{TiO}_{2} @ \mathrm{PPy}(n-\pi)$ heterojunctions. A synergistic effect between $\mathrm{Ag}-\mathrm{Ag}_{2} \mathrm{O}$ and PPy leads to higher photostability and a better electron/hole separation leads to an enhanced photocatalytic activity of $\mathrm{Ag} / \mathrm{TiO}_{2} @ \mathrm{PPy}$ under both UV and visible light irradiations.
\end{abstract}

Keywords: $\quad \mathrm{Ag}-\mathrm{Ag}_{2} \mathrm{O} / \mathrm{TiO}_{2} @$ polyprrrole heterojunction; photocatalysis; methylene blue; Degradation mechanism

\section{Introduction}

Heterogeneous photocatalytic degradation of pollutants by an $n$-type semiconductor, i.e., $\mathrm{TiO}_{2}$ nanoparticles, has been widely studied in the last decade [1]. Rutile and anatase polymorphs of $\mathrm{TiO}_{2}$ are the most studied structures, among which anatase shows much higher photocatalytic activity [2]. Meanwhile, rutile $\mathrm{TiO}_{2}$ has low band-gap energy $(\sim 3.02 \mathrm{eV})$ compared to anatase $\mathrm{TiO}_{2}(\sim 3.2)$, which allows it to absorb solar energy more efficiently than the anatase form, hence making it a suitable candidate for photocatalytic applications. However, the wide band gap of rutile $\mathrm{TiO}_{2}$ and poor quantum yield results in low photo efficiency, which limits its use in visible light [2,3]. In order to 
extend the photo response in visible light and improve the photocatalytic activity of $\mathrm{TiO}_{2}$, various doping, co-doping, composite, coupling, etc. techniques have been investigated and various materials with $\mathrm{TiO}_{2}$ such as carbon [4], $\mathrm{Pt}(\mathrm{II})$ [5], $\mathrm{CoFe}_{2} \mathrm{O}_{4}$ [6], N, Fe, Fe-N [7], Ag-polyaniline [8], etc. have gained much attention in the recent past. Among these, noble metals such as $\mathrm{Au}, \mathrm{Ag}, \mathrm{Pt}$, etc. have shown high photocatalytic enhancing property by inhibiting charge carrier recombination within the semiconductor materials [9]. Silver $\left(\mathrm{Ag}^{0} / \mathrm{Ag}^{+}\right)$is one of the most promising noble metals used to make visible light photoactive materials. $\mathrm{Ag}_{2} \mathrm{O}$ is a $p$-type semiconductor with energy $\sim 1.46 \mathrm{eV}$ and has been widely used as photocatalyst in single, binary, or multiple composite systems [10,11]. Under UV light irradiation, $\mathrm{Ag}_{2} \mathrm{O}$ behaves as an effective $\mathrm{e}^{-}$-absorbing agent, while under visible light irradiation it acts as an efficient photosensitizer [10,11]. However, $\mathrm{Ag}_{2} \mathrm{O}$ is photosensitive but its instability under light irradiation $\left(\mathrm{Ag}_{2} \mathrm{O} \rightarrow 2 \mathrm{Ag}+1 / 2 \mathrm{O}_{2}\right)$ is the main problem associated with its photocatalytic uses. Wang et al. [10] reported that $\mathrm{Ag}_{2} \mathrm{O}$ shows higher stability in the presence of metallic Ag. In an $\mathrm{Ag}-\mathrm{Ag}_{2} \mathrm{O}$ system, $\mathrm{Ag}$ acts as an electron scavenger, which prevents the reduction of $\mathrm{Ag}_{2} \mathrm{O}$. Therefore, the $\mathrm{Ag}-\mathrm{Ag}_{2} \mathrm{O}$ system may be an effective methodology to overcome stability problems [8,12]. Moreover, the $\mathrm{Ag}-\mathrm{Ag}_{2} \mathrm{O}$ system may enhance photocatalytic activity, increase the lifetime of the photocatalyst, and inhibit the leaching and aggregation of nano-sized semiconductor particles into the water $[7,13]$.

Recently, conducting polymers such as polypyrrole (PPy), polythiophene, and polyaniline have been used as photosensitizers to modify the photocatalyst semiconductors band. These polymers can efficiently donate electrons, act as hole transporters, have good interfacial electron transfer process, and prevent oxidation/reduction of metallic nanoparticles under visible light excitation [14,15]. Among these conducting polymers, PPy possesses high electrochemical reversibility, superior conductivity, and high polarizability, and can also be easily synthesized by electrochemical or chemical routes [14,16]. In addition, the high thermal and chemical stability of PPy makes it a promising material and a stable photosensitizer, which may enhance the photocatalytic activity of $\mathrm{TiO}_{2}$ [17]. Various reports on the photocatalytic applications of PPy-based materials such as AgCl/PPy, [18], PPy-TiO $-\mathrm{Fly}$ ash [19], $\mathrm{PPy} / \mathrm{Bi}_{2} \mathrm{WO}_{6}[12]$, etc. have shown high photocatalytic efficiency in visible light for the degradation of organic pollutants.

On the basis of the aforementioned considerations, it may be assumed that a multi-component nanocomposite of $\mathrm{Ag}-\mathrm{Ag}_{2} \mathrm{O}$, polypyrrole (PPy) and $\mathrm{TiO}_{2}$ would possess a narrow band gap and higher photocatalytic activity and thus might be successfully applied for visible light photocatalysis. Therefore, in this work, an $\mathrm{Ag} / \mathrm{TiO}_{2} @ P P y$ nanocomposite was synthesized and characterized by various techniques. The photocatalytic activity of the as-synthesized nanocomposite was evaluated for the degradation of methylene blue (MB) in an aqueous solution under UV and visible light irradiation. The photocatalytic activity of $\mathrm{Ag} / \mathrm{TiO}_{2} @ \mathrm{PPy}$ was also compared with two component composites i.e., $\mathrm{Ag} / \mathrm{TiO}_{2}$ and $\mathrm{TiO}_{2} @ P P y$.

In this work, an aqueous medium was used for the synthesis of a self-stabilized $A g-\mathrm{Ag}_{2} \mathrm{O}$ structure in the presence of pyrrole. In this synthesis, pyrrole acts as a reducing agent and undergoes oxidative polymerization in the presence of $\mathrm{Ag}^{+}$in aquatic conditions. This reaction was conducted in the homogeneous $\mathrm{TiO}_{2}$ suspension to deposit $\mathrm{Ag}-\mathrm{Ag}_{2} \mathrm{O}$ and $\mathrm{PPy}$ over the $\mathrm{TiO}_{2}$ surface. The main objective of this work is to stabilize and enhance the photocatalytic activity of $\operatorname{Ag}_{2} \mathrm{O}$ under solar irradiation. $\mathrm{Ag}_{2} \mathrm{O}$, when photo-reduced to $\mathrm{AgO}$, is unstable at room temperature and forms $\mathrm{Ag}^{0}$ and $\mathrm{O}_{2}\left(\mathrm{Ag}_{2} \mathrm{O} \rightarrow \mathrm{AgO}+\mathrm{Ag}, \mathrm{AgO} \rightarrow \mathrm{Ag}+1 / 2 \mathrm{O}_{2}\right)$ [10]. Under light irradiation, photo-generated electrons and holes from the conduction band (CB) and valence band (VB) band of $\mathrm{Ag}_{2} \mathrm{O}$, respectively, reduce $\mathrm{Ag}^{+}$ ions into metallic $\mathrm{Ag}$ and oxidize lattice $\mathrm{O}^{2-}$ to $\mathrm{O}_{2}$. For the stabilization of $\operatorname{Ag}_{2} \mathrm{O}$, the photo-generated electron and holes in $\mathrm{Ag}_{2} \mathrm{O}$ must be separated immediately before lattice $\mathrm{O}^{2-}$ oxidation and lattice $\mathrm{Ag}^{+}$reduction. For this purpose, simultaneous synthesis of $\mathrm{Ag}-\mathrm{Ag}_{2} \mathrm{O}-\mathrm{PPy}$ onto $\mathrm{TiO}_{2}$ has been done to stabilize and enhance the photocatalytic activity of $\mathrm{Ag}_{2} \mathrm{O}$. 


\section{Results and Discussion}

In this hybrid system, metallic $\mathrm{Ag}$ collects and channels the photo-generated electrons from $\mathrm{Ag}_{2} \mathrm{O} / \mathrm{TiO}_{2}$ while PPy is assumed to transfer photo-generated holes to the solid-solution interface $[10,20]$. To confirm the existence of $\mathrm{Ag}-\mathrm{Ag}_{2} \mathrm{O}$ and PPy in the $\mathrm{Ag} / \mathrm{TiO}_{2} @ P P y$ heterostructure, XPS analysis was performed as shown in Figure 1. The high-resolution spectra for $\mathrm{Ag} 3 \mathrm{~d}$ demonstrate that silver is present in more than one oxidation state. The peaks appearing at 367.63 and $373.65 \mathrm{eV}$ correspond to the $\mathrm{Ag} 3 \mathrm{~d}_{5 / 2}$ and $\mathrm{Ag} 3 \mathrm{~d}_{3 / 2}$, respectively, representing silver in $\mathrm{Ag}^{+}\left(\mathrm{Ag}_{2} \mathrm{O}\right)$ oxidation state. The other peaks of $\mathrm{Ag} 3 \mathrm{~d}_{5 / 2}$ and $\mathrm{Ag} 3 \mathrm{~d}_{3 / 2}$ peaks at 368.1 and $374.11 \mathrm{eV}$, respectively, with a separation of $6 \mathrm{eV}$, confirm the existence of silver in the $\mathrm{Ag}^{0}$ state. These binding energies values are in good agreement with the reported values for $\mathrm{Ag}^{0}$ and $\mathrm{Ag}_{2} \mathrm{O}[10,21,22]$. The binding energies for 1 Os peaks located at 530.1, 531.66 and $533.84 \mathrm{eV}$ are ascribed to the $\mathrm{O}^{2-}$ in $\mathrm{TiO}_{2}$ and $\mathrm{Ag}_{2} \mathrm{O}$, respectively [22,23]. The characteristic peaks $\left(\mathrm{Ti}^{4+}\right)$ of $\mathrm{Ti}_{2} \mathrm{p}_{3 / 2}$ and $2 \mathrm{p}_{1 / 2}$ appeared at 458.84 and $464.68 \mathrm{eV}$, respectively [22]. The $\mathrm{C} 1$ s peaks of PPy, corresponding to the binding energies at 285 and $286.09 \mathrm{eV}$, can be attributed to the $\mathrm{C}-\mathrm{C}$ and $\mathrm{C}-\mathrm{N}$ groups and the other $\mathrm{C} 1$ s peak at $289.05 \mathrm{eV}$ is attributed to the electronic transition on PPy ring [24]. The characteristic spectrum of pyrrolylium nitrogen $(-\mathrm{NH}-)$ as $\mathrm{N} 1 \mathrm{~s}^{\prime}$ single major component appears at $399.7 \mathrm{eV}$, while the $\mathrm{N} 1$ s peak in our case appeared at low binding energy i.e., at $397.38 \mathrm{eV}$, which may be due to the dehydrogenation of pyrrolylium nitrogen $[25,26]$.
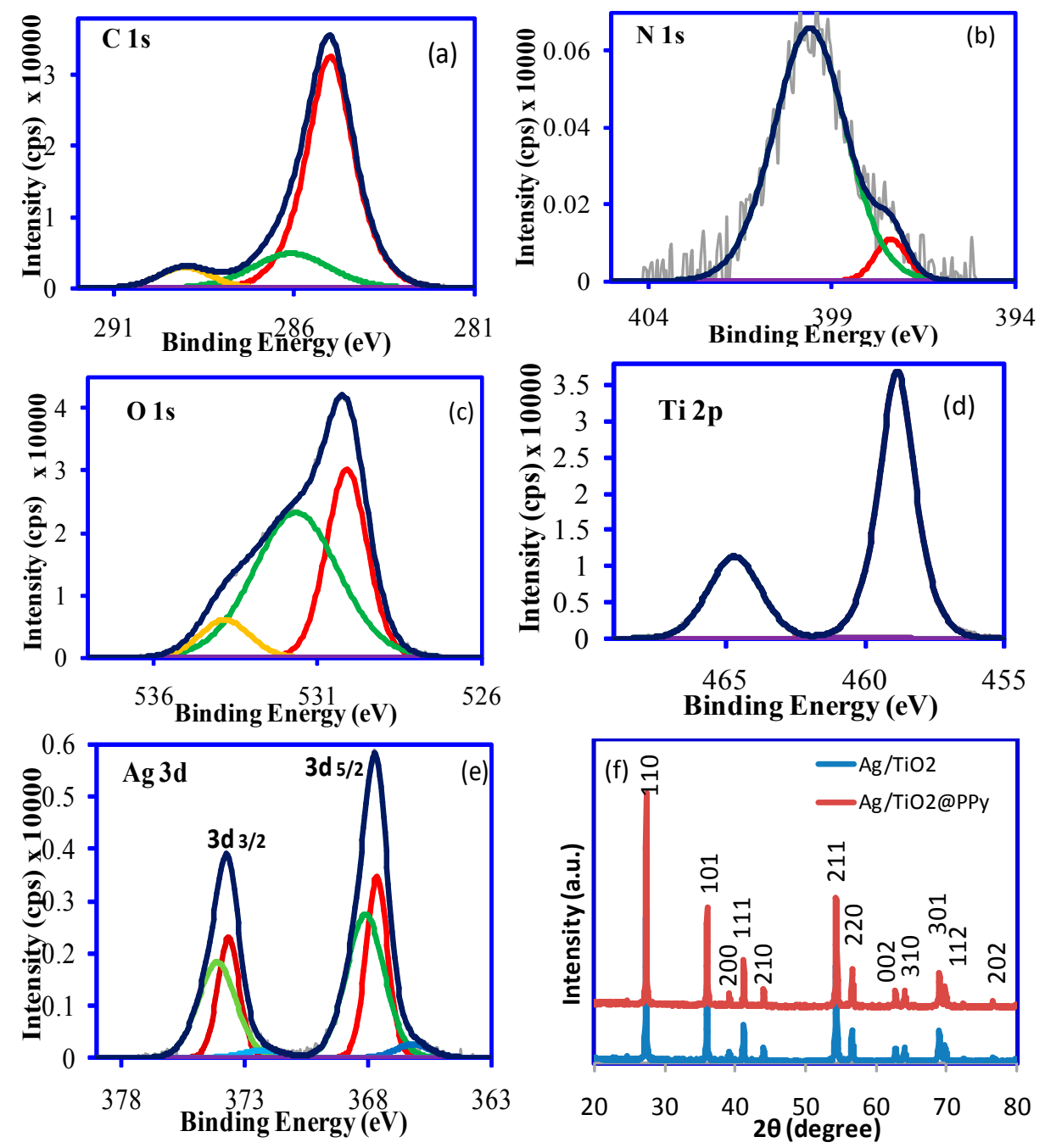

Figure 1. XPS analysis of $\mathrm{Ag} / \mathrm{TiO}_{2} @ P P y(\mathbf{a}-\mathbf{e})$ and XRD patterns of $\mathrm{Ag} / \mathrm{TiO}_{2}$ and $\mathrm{Ag} / \mathrm{TiO}_{2} @ \mathrm{PPy}(\mathbf{f})$. 
XRD spectra of $\mathrm{Ag} / \mathrm{TiO}_{2}$ and $\mathrm{Ag} / \mathrm{TiO}_{2} @ P P y$ heteroconjugation are shown in Figure 1f. The XRD analysis showed highly crystalline rutile phase of $\mathrm{TiO}_{2}$ (JCPDS card No. 01-071-0650) without other detectable impurities, suggesting that the presence of $\mathrm{Ag}_{2} \mathrm{O}-\mathrm{Ag}$ and PPy did not change the lattice structure of $\mathrm{TiO}_{2}$. However, the peaks for $\mathrm{Ag}_{2} \mathrm{O}-\mathrm{Ag}$ and PPy are not observed due to its low concentration. Similar explanations have also been reported by several other researchers for indistinct XRD peaks in their respective composite systems $[27,28]$. The crystallite size of $\mathrm{Ag} / \mathrm{TiO}_{2}$ and $\mathrm{Ag} / \mathrm{TiO}_{2} @ \mathrm{PPy}$ hybrid structures were found to be in the ranges of 34.3-61.9 nm and $61.3-80.8 \mathrm{~nm}$, respectively.

To study the surface morphology and presence of $\mathrm{Ag}$ in $\mathrm{Ag} / \mathrm{TiO}_{2} @ \mathrm{PPy}$ nanocomposite, SEM and TEM analysis were performed as shown in Figure 2. The SEM image (Figure 2a) shows the highly irregular shape of the nanocomposite with large globules of different sizes. A thorough examination at higher magnification (Figure $2 \mathrm{~b}$ ) clearly shows $\mathrm{Ag}$ particles deposited on the $\mathrm{TiO}_{2} @ \mathrm{PPy}$ polymer system. The TEM images of $\mathrm{Ag} / \mathrm{TiO}_{2} @ \mathrm{PPy}$ (Figure 2c,d) clearly demonstrate that spherical Ag nanoparticles are immobilized on the PPy-coated $\mathrm{TiO}_{2}$, hence confirming the successful synthesis of an $\mathrm{Ag} / \mathrm{TiO}_{2} @$ PPy hybrid material.
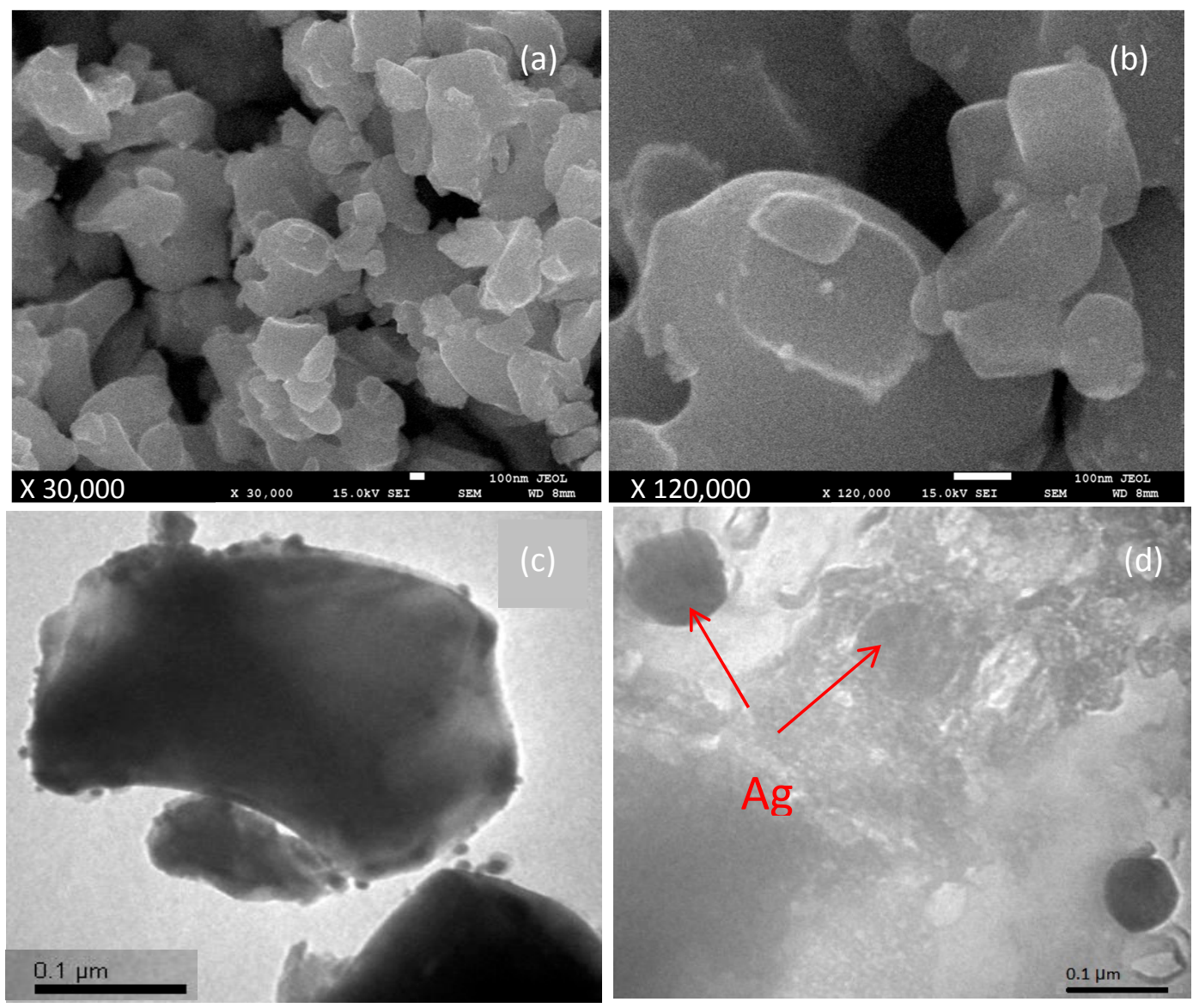

Figure 2. Surface morphology of $\mathrm{Ag} / \mathrm{TiO}_{2} @ P P y$ composite, SEM images (a,b) and TEM (c,d).

The optical properties of $\mathrm{Ag} / \mathrm{TiO}_{2}, \mathrm{TiO}_{2} @ \mathrm{PPy}$, and $\mathrm{Ag} / \mathrm{TiO}_{2} @ P P y$ were studied by UV-visible diffusion reflectance spectroscopy and the spectra are shown in Figure 3. All the studied composites exhibit the sharp adsorption edge $<400 \mathrm{~nm}$, indicating the strong light absorption capability in both $\mathrm{UV}$ and visible light ranges. The absorption band in the UV region i.e., $>380 \mathrm{~nm}$ is the characteristic band of Ti-O [29]. The spectrum of $\mathrm{TiO}_{2} @ \mathrm{PPy}$ and $\mathrm{Ag} / \mathrm{TiO}_{2} @ \mathrm{PPy}$ is above $\mathrm{Ag} / \mathrm{TiO}_{2}$, which can be attributed to the $\pi-\pi^{*}$ transition of the polypyrrole backbone. The optical band gaps of $\mathrm{Ag} / \mathrm{TiO}_{2}$, 
$\mathrm{TiO}_{2} / \mathrm{PPy}$, and $\mathrm{Ag} / \mathrm{TiO}_{2} / \mathrm{PPy}$ are $2.97,2.89$, and $2.91 \mathrm{eV}$, respectively. As observed from the band gap analysis, the incorporation of $\mathrm{Ag}$ and $\mathrm{PPy}$ onto $\mathrm{TiO}_{2}$ significantly narrowed the band gap energy. Therefore, the UV and visible light response of the hybrid materials improved, which will result in enhanced photocatalytic properties.

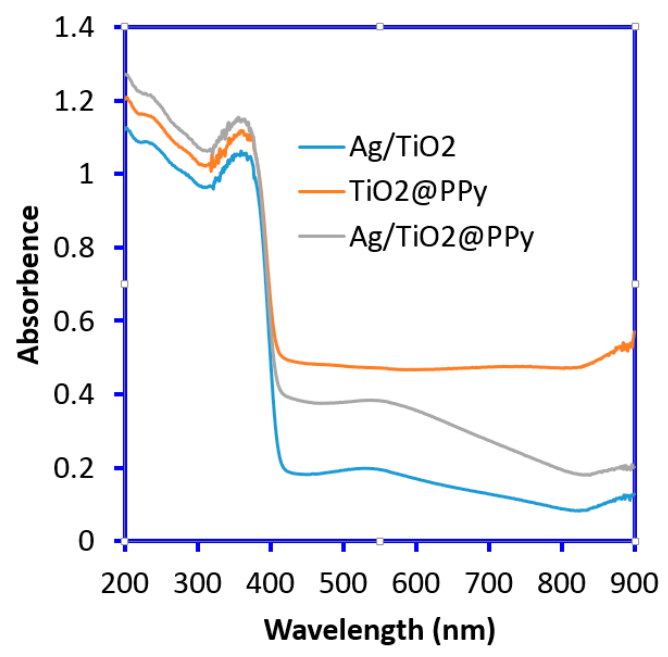

Figure 3. UV-vis spectra of $\mathrm{Ag} / \mathrm{TiO}_{2}, \mathrm{TiO}_{2} @ P P y$, and $\mathrm{Ag} / \mathrm{TiO}_{2} @ P P y$ heterostructures.

The photocatalytic activity of $\mathrm{Ag} / \mathrm{TiO}_{2} @ \mathrm{PPy}$ heterostructure was comparatively studied with $\mathrm{Ag} / \mathrm{TiO}_{2}$ and $\mathrm{TiO}_{2} @ P P y$ by using $\mathrm{MB}$ as a model pollutant in aqueous solution under UV and visible light irradiation. The degradation of $\mathrm{MB}$ as a function of irradiation time is shown in Figure 4. From Figure 4, it can be seen that the degradation of MB in UV irradiation was higher compared to the visible light irradiation and the photocatalytic behavior followed the order: $\mathrm{TiO}_{2}<\mathrm{TiO}_{2} @ \mathrm{PPy}<\mathrm{Ag} / \mathrm{TiO}_{2}<$ $\mathrm{Ag} / \mathrm{TiO}_{2} @ \mathrm{PPy}$. The observed higher photocatalytic activity of Ag $/ \mathrm{TiO}_{2} @ P P y$ than $\mathrm{TiO}_{2} @ \mathrm{PPy}, \mathrm{Ag} / \mathrm{TiO}_{2}$, and $\mathrm{TiO}_{2}$ may be due to the fact that PPy and $\mathrm{Ag}$ nanoparticles may act as an interfacial charge carrier in the $\mathrm{Ag}-\mathrm{TiO}_{2}-\mathrm{PPy}$ system, which leads to the prevention of electron-hole $\left(\mathrm{e}^{-} / \mathrm{h}^{+}\right)$pair recombination, thereby increasing the photocatalytic activity. Moreover, the effectiveness of a ternary composite system $\left(\mathrm{Ag} / \mathrm{TiO}_{2} @ P P y\right)$ was comparatively enhanced due to the synergistic effect of $\mathrm{Ag}\left(\mathrm{Ag}-\mathrm{Ag}_{2} \mathrm{O}\right)$, $\mathrm{TiO}_{2}$ and PPy $[29,30]$. On the basis of this study, the $\mathrm{Ag} / \mathrm{TiO}_{2} @ \mathrm{PPy}$ composite was used for further photocatalytic studies.
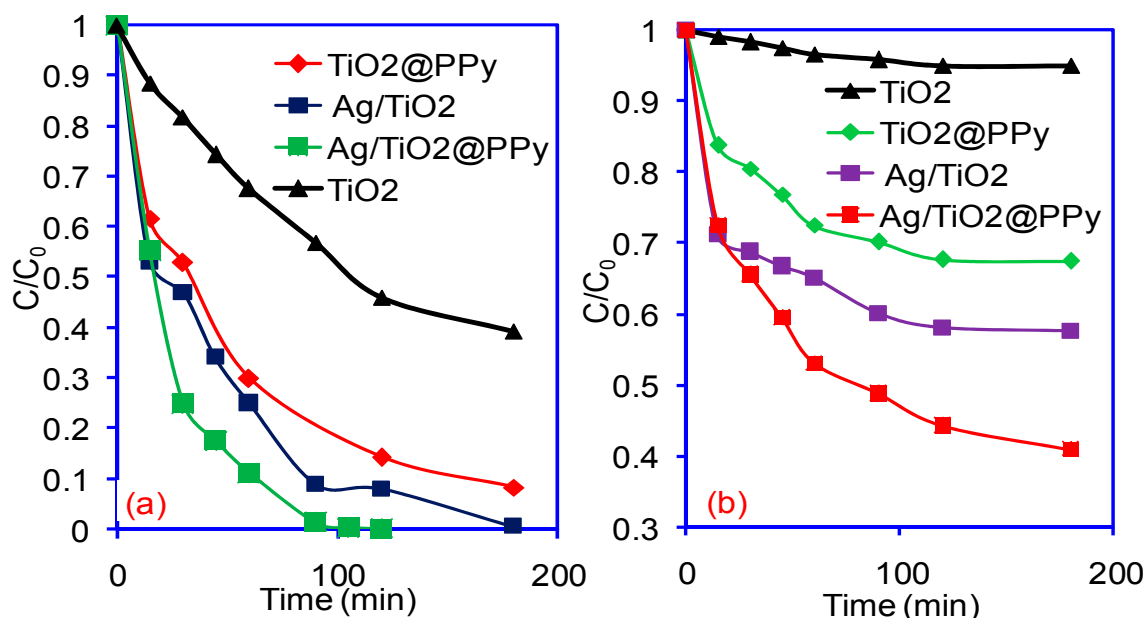

Figure 4. Comparison of MB photocatalytic degradation efficiency of synthesized heterojunctions under (a) UV and (b) visible light irradiation. 
The solution $\mathrm{pH}$ plays an important role in the interaction of a dye with the photocatalyst surface and their degradation. The UV and visible light photocatalytic activity of $\mathrm{Ag} / \mathrm{TiO}_{2} @ \mathrm{PPy}$ as a function of initial dye solution $\mathrm{pH}$ are shown in Figure 5. The degradation of $\mathrm{MB}$ is strongly affected by the solution $\mathrm{pH}$ and it increased with the increase in the solution $\mathrm{pH}$ from 3.0 to 9.0. The maximum degradation was observed at $\mathrm{pH} 9.0$ for both UV and visible light. The observed behavior could be explained on the basis of surface charge on the $\mathrm{Ag} / \mathrm{TiO}_{2} @ \mathrm{PPy}$ at different solution $\mathrm{pH}$ values. Lower degradation efficiency of $\mathrm{Ag} / \mathrm{TiO}_{2} @ \mathrm{PPy}$ for $\mathrm{MB}$ in acidic solution was due to protonation of $\mathrm{Ag} / \mathrm{TiO}_{2} @ \mathrm{PPy}\left(\mathrm{NH}_{2}{ }^{+}\right.$in $\left.\mathrm{PPy}\right)$, which generates a positive surface charge and shows electrostatic repulsion with the positively charged $\mathrm{MB}$ ions [31,32]. As the solution $\mathrm{pH}$ increases from acidic to alkaline, the surface charge starts to turn negative and degradation of $\mathrm{MB}$ increases. At $\mathrm{pH}$ 9.0, deprotonation of nitrogen atoms of PPy takes place and the surface of $\mathrm{Ag} / \mathrm{TiO}_{2} @ \mathrm{PPy}$ becomes negatively charged, which interacts with cationic $\mathrm{MB}$ ions electrostatically, resulting in an enhancement of the photocatalytic degradation of MB [31,33]. Besides electrostatic forces, $\pi-\pi$ stacking, hydrogen bonding, and van der Waals forces are also expected to be involved in the interaction of MB with $\mathrm{Ag} / \mathrm{TiO}_{2} @ \mathrm{PPy}$. Due to these forces, reasonable photocatalytic degradation of MB was observed at pH 5.0 and 7.0.
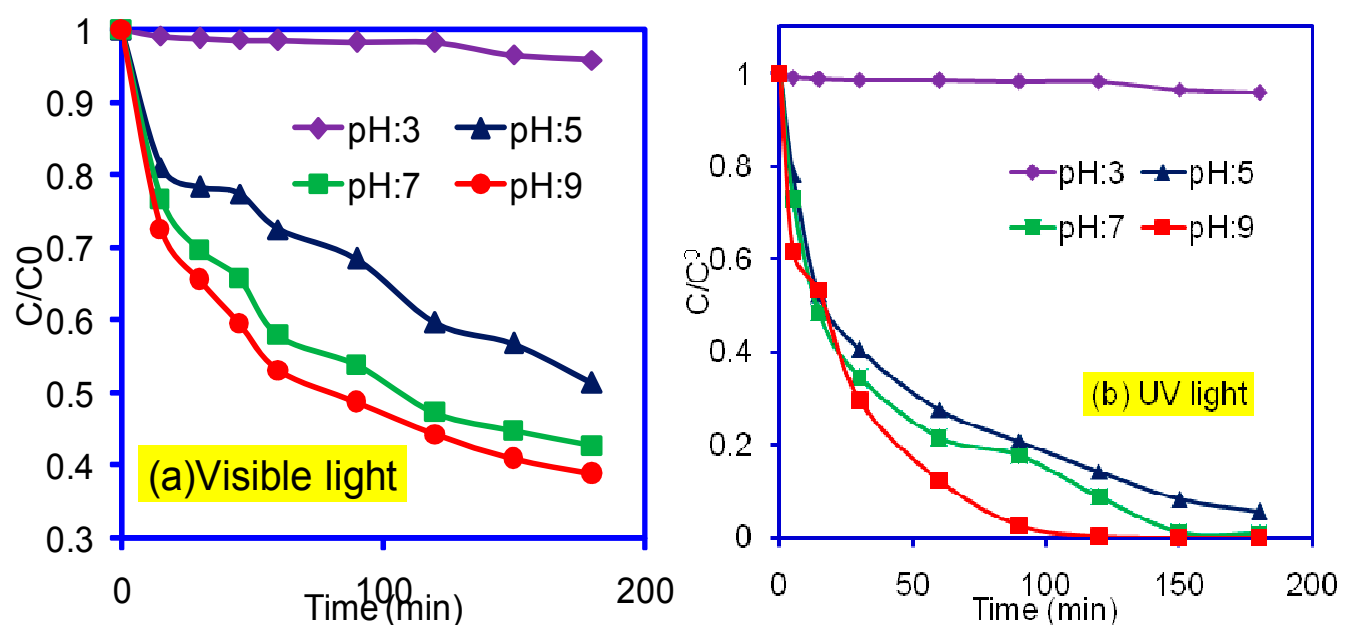

Figure 5. Effect of solution $\mathrm{pH}$ on $\mathrm{MB}$ photodecomposition using $\mathrm{Ag} / \mathrm{TiO}_{2} @ \mathrm{PPy}$ heterostructure under UV and visible light irradiation.

The rate constant for $\mathrm{MB}$ degradation was calculated using a first-order reaction kinetic model: $\ln \left(C / C_{0}\right)=-k t$. where $C_{0}$ and $C$ denotes the concentration of $\mathrm{MB}$ before and after photocatalysis, respectively; and $k$ and $t$ are the rate constant and irradiation time, respectively. The values of rate constant calculated from the linear relation of $\ln \left(C / C_{0}\right)$ vs. $t$ are mentioned in Table 1 . It can be seen from Table 1 that the rate constant values increased with the increase in the solution $\mathrm{pH}$, confirming that a higher $\mathrm{pH}$ was favorable for $\mathrm{MB}$ degradation in an aqueous solution. Hence, the efficiency of $\mathrm{Ag} / \mathrm{TiO}_{2} @ P P y$ under UV irradiation was much higher than the visible light photocatalytic degradation of $\mathrm{MB}$. These results are in agreement with the abovementioned data. The higher efficacy of $\mathrm{Ag} / \mathrm{TiO}_{2} @ \mathrm{PPy}$ under UV light irradiation is due to the higher photon absorption by all three components $\left(\mathrm{Ag}, \mathrm{TiO}_{2}\right.$, and PPy) while in visible light irradiation only $\mathrm{Ag}$ and PPy can be photo-excited [11]. 
Table 1. First order rate constants for the degradation of $\mathrm{MB}$ using $\mathrm{Ag} / \mathrm{TiO}_{2} @ \mathrm{PPy}$.

\begin{tabular}{ccccc}
\hline $\mathbf{p H}$ & $\boldsymbol{k}(\mathbf{U V})\left(\mathbf{m i n}^{-\mathbf{1}}\right)$ & $\boldsymbol{R}^{\mathbf{2}}$ & $\boldsymbol{k}($ Visible $)\left(\mathbf{m i n}^{-\mathbf{1}}\right)$ & $\boldsymbol{R}^{\mathbf{2}}$ \\
\hline 3 & 0.000 & 0.834 & 0.000 & 0.488 \\
5 & 0.014 & 0.987 & 0.002 & 0.987 \\
7 & 0.024 & 0.929 & 0.003 & 0.955 \\
9 & 0.044 & 0.968 & 0.003 & 0.947 \\
\hline
\end{tabular}

The effect of initial MB concentration in aquatic solution was studied in the range of 4 to $20 \mathrm{mg} / \mathrm{L}$, as depicted in Figure 6. At lower concentrations almost 100\% degradation of MB was observed under UV and visible light irradiation. As the concentration of MB increased from 4 to $20 \mathrm{mg} / \mathrm{L}$, the degradation efficiency decreased from $99.62 \%$ to $83.9 \%$ under UV irradiation, while in visible light the efficiency decreased from $99.37 \%$ to $18.85 \%$. The reduction in the degradation rate of $\mathrm{MB}$ can be explained on the basis of the higher surface coverage of $\mathrm{Ag} / \mathrm{TiO}_{2} @ \mathrm{PPy}$ with $\mathrm{MB}$ ions, which suppressed the production of $\bullet \mathrm{OH}$ radicals [34]. Moreover, the increase in the optical density of the $\mathrm{MB}$ solution as a consequence of increasing the concentration of $\mathrm{MB}$ results in a decrease in the light penetration in the solution. Therefore, fewer photons reach the $\mathrm{Ag} / \mathrm{TiO}_{2} @ \mathrm{PPy}$ surface due to the $\mathrm{UV} /$ visible light screening effect of MB itself. This effect reduces the generation of $\mathrm{O}_{2}{ }^{\bullet-}$ and ${ }^{\bullet} \mathrm{OH}$, which causes a decrease in the efficiency of the photocatalytic reaction [34,35].

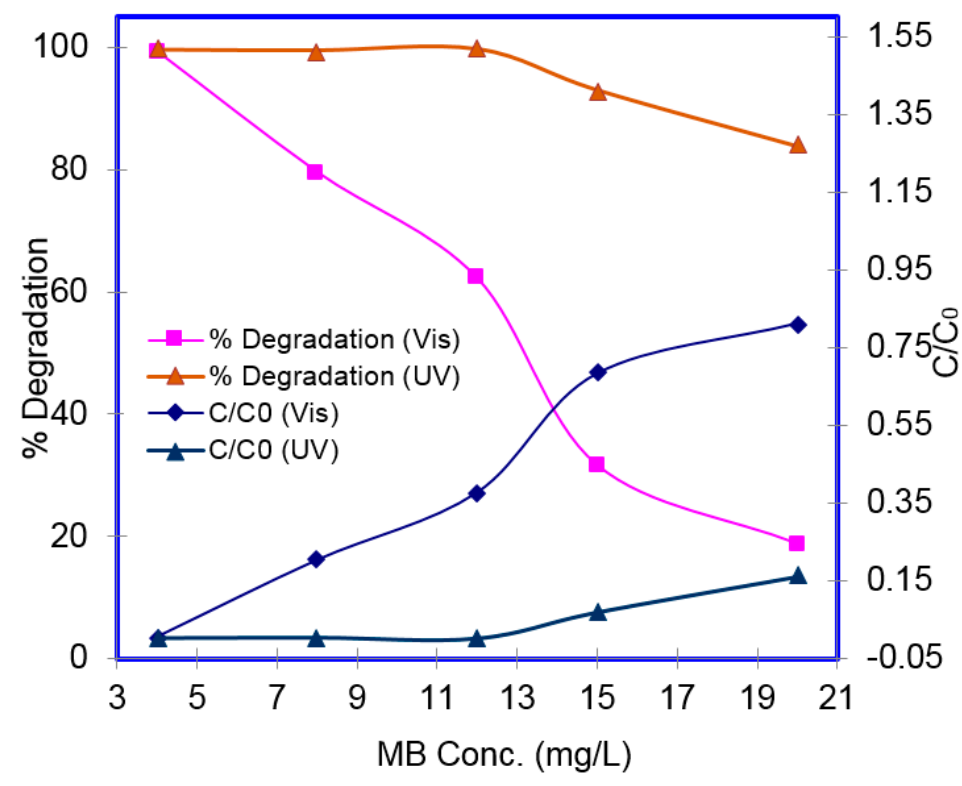

Figure 6. Effect of initial dye concentration on MB photocatalytic degradation.

The aforementioned results confirmed that a $\pi$-conjugated $\mathrm{Ag} / \mathrm{TiO}_{2} @ \mathrm{PPy}$ heterojunction photocatalyst has higher photocatalytic activity than $\mathrm{Ag} / \mathrm{TiO}_{2}$ and $\mathrm{TiO}_{2} @ P P y$ under both UV and visible light irradiation. A schematic illustration for $\mathrm{e}^{-} / \mathrm{h}^{+}$separation in $\mathrm{Ag} / \mathrm{TiO}_{2} @ \mathrm{PPy}$ heterojunction under UV and visible light irradiation have been shown in Figure 7. Under UV light irradiation, both $\mathrm{Ag}_{2} \mathrm{O}\left(\mathrm{Ag}_{2} \mathrm{O}+\mathrm{h} v \rightarrow \mathrm{h}^{+}+\mathrm{e}^{-}\right)$and $\mathrm{TiO}_{2}\left(\mathrm{TiO}_{2}+\mathrm{h} v \rightarrow \mathrm{h}^{+}+\mathrm{e}^{-}\right)$could be photo-excited to generate $\mathrm{e}^{-}$and $\mathrm{h}^{+}$pairs, while under visible light $\mathrm{Ag}_{2} \mathrm{O}$ and $\mathrm{PPy}\left(\mathrm{PPy}+\mathrm{h} v \rightarrow \mathrm{h}^{+}+\mathrm{e}^{-}\right)$[36] get excited due to the narrow band gap $(1.3 \mathrm{eV}$ and $2.5 \mathrm{eV})$, thereby producing $\mathrm{e}^{-}$and $\mathrm{h}^{+}$pairs. The $\mathrm{CB}$ level of $\mathrm{Ag}_{2} \mathrm{O}$ has a higher positive potential $(+0.2 \mathrm{eV}$ vs. SHE) compared with the single electron reduction of $\mathrm{O}_{2}\left(-0.046 \mathrm{~V}\right.$ vs. SHE). Therefore, photogenerated $\mathrm{e}^{-}$from $\mathrm{Ag}_{2} \mathrm{O}$ can be transferred by metallic $\mathrm{Ag}\left(\mathrm{Ag}^{+} / \mathrm{Ag}: 0.7991 \mathrm{~V}\right.$, vs. SHE) to the $\mathrm{O}_{2}$ and thereby generate $\mathrm{O}_{2}{ }^{\bullet-}$ and ${ }^{\bullet} \mathrm{OH}$ radicals $\left(\mathrm{e}^{-}+\mathrm{O}_{2}+\right.$ $\left.\mathrm{H}_{2} \mathrm{O} \rightarrow \mathrm{O}_{2}{ }^{\bullet-}+{ }^{\bullet} \mathrm{OH}\right)$ through a chain of reactions [10,21]. In the combined system $\mathrm{Ag} / \mathrm{TiO}_{2} @ \mathrm{PPy}, \pi$ 
orbital becomes the highest occupied molecular orbital (HOMO) and the lowest occupied molecular orbital level (LUMO) of PPy is energetically higher than the CB edge of rutile $\mathrm{TiO}_{2}(3.0 \mathrm{eV})$ [9]. When PPy is harvested in visible light, the photogenerated $\mathrm{e}^{-}$are transferred to the excited state and these $\mathrm{e}^{-}$can be readily injected into the $\mathrm{CB}$ of $\mathrm{TiO}_{2}$ and photogenerated $\mathrm{h}^{+}$channeled by the PPy to the solid solution interface, which generates hydroxyl radicals $\left(\mathrm{h}^{+}+\mathrm{H}_{2} \mathrm{O} \rightarrow \bullet \mathrm{OH}+\mathrm{H}^{+}\right)$. The photogenerated $\mathrm{e}^{-}$trapped by the catalyst surface adsorbs $\mathrm{H}_{2} \mathrm{O}$ and $\mathrm{O}_{2}$, which produces superoxide radical anions $\left(\mathrm{O}_{2}{ }^{\bullet-}\right.$, OOH, and $\left.\mathrm{OH}^{-}\right)$, while photogenerated $\mathrm{h}^{+}$reacts with $\mathrm{OH}^{-}$and $\mathrm{H}_{2} \mathrm{O}$ to generate $\mathrm{HO}^{\bullet}$ and $\mathrm{H}^{+}$ species [37]. As a result, $\mathrm{Ag} / \mathrm{TiO}_{2} @ \mathrm{PPy}$ had a fast charge separation and enhanced the life of $\mathrm{e}^{-} / \mathrm{h}^{+}$ recombination, resulting in higher and faster photocatalytic activity.

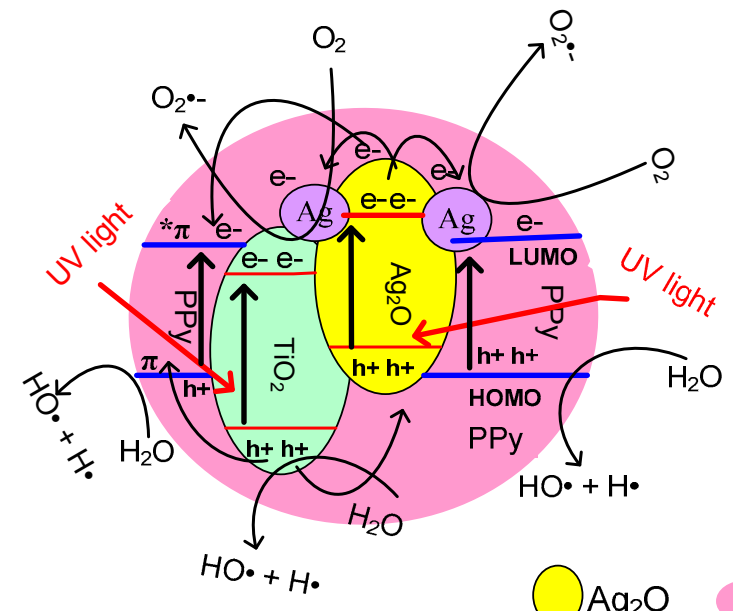

(a) UV light

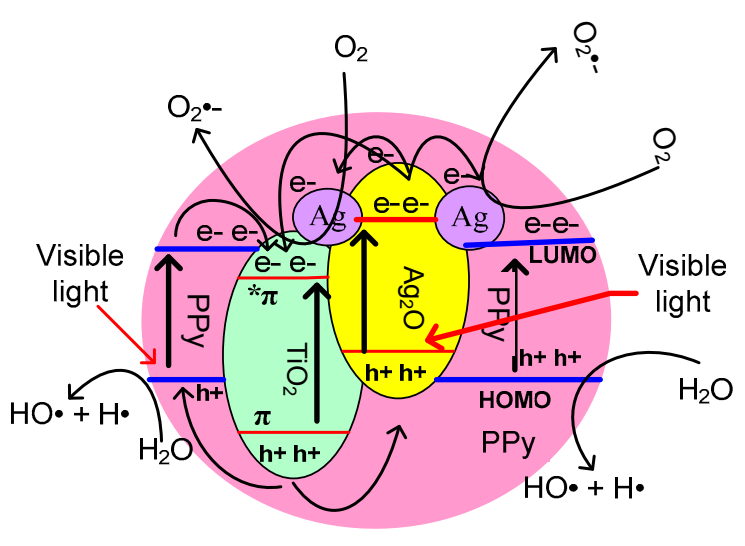

Polypyrrole

Figure 7. Schematic representation of possible electron/hole pair separation mechanism of the $\mathrm{Ag}-\mathrm{Ag}_{2} \mathrm{O} / \mathrm{TiO}_{2} @ \mathrm{PPy}$ heterostructure under (a) UV and (b) visible light irradiation.

\section{Materials and Methods}

Titanium dioxide (rutile $\mathrm{TiO}_{2}$ ) from Alfa-Aesar (Beijing, China) was used as the photocatalyst support. Pyrrole and $\mathrm{AgNO}_{3}$ were purchased from Sigma-Aldrich (Taufkirchen, Germany), and used as received. Methylene blue (MB) $\left[\mathrm{C}_{16} \mathrm{H}_{18} \mathrm{~N}_{3} \mathrm{SCl}\right.$ ) was purchased from Techno Pharma (Bahadurgarh, India). The aqueous solution of $\mathrm{MB}$ was prepared by dissolving $1 \mathrm{~g}$ of dye in $1 \mathrm{~L}$ solution and dilution was performed to get the desired concentration of MB for photocatalytic degradation studies.

\subsection{Synthesis of $\mathrm{Ag} / \mathrm{TiO}_{2}$ Nanocomposite}

A mixture of rutile $\mathrm{TiO}_{2}(1.5 \mathrm{~g})$ and $0.26 \mathrm{~g} \mathrm{AgNO}_{3}$ (dissolved in $10 \mathrm{~mL} \mathrm{H}_{2} \mathrm{O}$ ) was mixed well and dried in an oven at $60^{\circ} \mathrm{C}$ for $12 \mathrm{~h}$. This mixture was then spread on the glass plate and placed under a UV lamp at a distance of $10 \mathrm{~cm}$. Thereafter, the mixture was irradiated with $302 \mathrm{~nm}$ light source at room temperature for $6 \mathrm{~h}$ with occasional mixing to ensure homogeneity.

\subsection{Synthesis of $\mathrm{TiO}_{2} @ P P y$ and $\mathrm{Ag} / \mathrm{TiO}_{2} @ P P y$ Nanocomposite}

For the synthesis of $\mathrm{TiO}_{2} @ P P y$, first $1.5 \mathrm{~g}$ of rutile $\mathrm{TiO}_{2}$ was dispersed in $14 \mathrm{~mL} \mathrm{H}_{2} \mathrm{O}$ at room temperature, to which $0.26 \mathrm{~g} \mathrm{AgNO}_{3}$ (dissolved in $10 \mathrm{~mL} \mathrm{H}_{2} \mathrm{O}$ ) and $6 \mathrm{~mL}$ pyrrole solution was added and thereafter the entire system was put under stirring conditions. To the above dispersion of pyrrole, $\mathrm{AgNO}_{3}$, and $\mathrm{TiO}_{2}$, the solution of oxidant $0.27 \mathrm{~g}$ of $\mathrm{FeCl}_{3}$ (dissolved in $10 \mathrm{~mL} \mathrm{H}_{2} \mathrm{O}$ ) was added. A greenish-black color indicated the start of the polymerization process and the reaction was left to occur for $6 \mathrm{~h}$. The resulting composite was thereafter filtered and washed with an excess of water, ethanol, and acetone to remove the PPy oligomers, unreacted oxidant, and other impurities. The prepared 
$\mathrm{Ag} / \mathrm{TiO}_{2} @ \mathrm{PPy}$ nanocomposite was dried in an air oven for $24 \mathrm{~h}$ at $80^{\circ} \mathrm{C}$ and stored in a desiccator for its further use. A $\mathrm{TiO}_{2} @ \mathrm{PPy}$ nanocomposite was also prepared similarly in the absence of $\mathrm{AgNO}_{3}$.

\subsection{Characterization}

The morphology of $\mathrm{Ag} / \mathrm{TiO}_{2} @ \mathrm{PPy}$ was studied by field emission scanning electron microscopy (FESEM) (JSM-7500 F; JEOL, Tokyo, Japan) and transmission electron microscopy (TEM) (model Tecnai G2 F20 Super Twin) at $200 \mathrm{kV}$ with LaB6 emitter. The UV-vis spectra of Ag/ $/ \mathrm{TiO}_{2}, \mathrm{TiO}_{2} @ P P y$ and $\mathrm{Ag} / \mathrm{TiO}_{2} @ \mathrm{PPy}$ were recorded with a Perkin Elmer UV-visible diffuse reflectance spectrophotometer in the range of 200-900 nm. X-ray photoelectron spectroscopy (XPS) measurements were recorded on a SPECS GmbH, (Berlin, Germany) spectrometer using a non-monochromatic $\mathrm{Mg}-\mathrm{K} \alpha$ (1253.6 eV). X-ray source. X-ray diffraction (XRD) spectra of $\mathrm{Ag} / \mathrm{TiO}_{2}$ and $\mathrm{Ag} / \mathrm{TiO}_{2} @ P P y$ were recorded by an Ultima-IV (Rigaku, Japan) diffractometer using $\mathrm{Cu} \mathrm{K} \alpha$ radiation.

\subsection{Photocatalytic Activity}

The photocatalytic degradation of MB under ultraviolet-C and visible light irradiation (112 W) was conducted in a 200-mL Pyrex beaker containing $100 \mathrm{~mL}$ dye solution under continuous aeration and magnetic stirring. The photocatalytic reactions at a fixed photocatalyst mass $(0.1 \mathrm{~g})$ were performed by varying the operational conditions such as solution $\mathrm{pH}$ (from 3 to 9), reaction time (between 5 and $180 \mathrm{~min}$ ), and initial $\mathrm{MB}$ concentration (from 4 to $20 \mathrm{mg} / \mathrm{L}$ ). Before starting the photocatalytic reactions, the solutions were kept in the dark for $30 \mathrm{~min}$ for the adsorption MB onto the materials and then the solutions were illuminated with UV/visible light. After photocatalytic reaction, the solutions were filtered through a $0.22-\mu \mathrm{m}$ syringe filter and the amount of $\mathrm{MB}$ remaining in the supernatant solution was determined at a maximum wavelength of $665 \mathrm{~nm}$ using a HACH LANGE DR-6000 UV-visible spectrometer.

\section{Conclusions}

$\mathrm{Ag} / \mathrm{TiO}_{2}, \mathrm{TiO}_{2} @ \mathrm{PPy}$, and $\mathrm{Ag} / \mathrm{TiO}_{2} @ P P y$ nanocomposites were successfully synthesized. XPS studies indicated that $\mathrm{Ag}$ was present in metallic and ionic forms. The UV-visible absorption studies showed that all the synthesized composites are effective visible light sensitizers. $\mathrm{Ag} / \mathrm{TiO}_{2} @ \mathrm{PPy}$ showed superior photocatalytic activity in comparison to $\mathrm{Ag} / \mathrm{TiO}_{2}$ and $\mathrm{TiO}_{2} @ \mathrm{PPy}$ under UV and visible light. The superior photocatalytic activity of $\mathrm{Ag} / \mathrm{TiO}_{2} @ \mathrm{PPy}$ heterojunction may be due to the higher $\mathrm{e}^{-} / \mathrm{h}+$ charge separation (there is a built-in electrostatic field at the heterojunction). PPy plays the role of photosensitizer and electron accepter in order to enhance the photodecomposition of $\mathrm{MB}$ in aquatic solution. The maximum photocatalytic activity of $\mathrm{Ag} / \mathrm{TiO}_{2} @ \mathrm{PPy}$ for $\mathrm{MB}$ was observed at $\mathrm{pH} 9$ and the pseudo-first order rate constant values were 0.044 and $0.003 \mathrm{~min}^{-1}$ under UV and visible light irradiation, respectively. The effect of initial dye concentration revealed that the degradation of $\mathrm{MB}$ decreased from $100 \%$ to $18.85 \%$ under UV light and from $100 \%$ to $83 \%$ in visible light when the MB concentration increased from 4 to $20 \mathrm{mg} \cdot \mathrm{L}^{-1}$. These results suggest that $\mathrm{Ag} / \mathrm{TiO}_{2} @ \mathrm{PPy}$ could be used as a promising material for the application of organic pollutant photodegradation in a vast variety of areas.

Acknowledgments: This project was supported by the NSTIP strategic technologies program in the Kingdom of Saudi Arabia - Project No (11-ENE1531-03). The authors also, acknowledge with thanks Science and Technology Unit, King Abdulaziz University for technical support.

Author Contributions: Mohamed A Barakat and Reda M. El-Shishtawy designed this work. Reda M. El-Shishtawy synthesized the materials. Rajeev Kumar conducted the experimental work and the manuscript was written by Rajeev Kumar and Mohamed A. Barakat.

Conflicts of Interest: The authors declare no conflict of interest. 


\section{References}

1. Curti, M.; Bahnemann, D.W.; Mendive, C.B. Mechanisms in Heterogeneous photocatalysis. In Reference Module in Materials Science and Materials Engineering; Elsevier: Amsterdam, The Netherlands, 2016. [CrossRef]

2. Paez, C.A.; Poelman, D.; Pirard, J.P.; Heinrichs, B. Unpredictable photocatalytic ability of $\mathrm{H}_{2}$-reduced rutile- $\mathrm{TiO}_{2}$ xerogel in the degradation of dye-pollutants under UV and visible light irradiation. Appl. Catal. $B$ 2010, 94, 263-271. [CrossRef]

3. Liua, X.; Zhanga, H.; Liu, C.; Chen, J.; Li, G.; An, T.; Wong, P.K.; Zhao, H. UV and visible light photoelectrocatalytic bactericidal performance of $100 \%\{111\}$ faceted rutile $\mathrm{TiO}_{2}$ photoanode. Catal. Today 2014, 224, 77-82. [CrossRef]

4. McEvoy, J.G.; Cui, W.; Zhang, Z. Degradative and disinfective properties of carbon-doped anatase-rutile $\mathrm{TiO}_{2}$ mixtures under visible light irradiation. Catal. Today 2013, 207, 191-199. [CrossRef]

5. Egerton, T.A.; Purnama, H.; Mattinson, J.A. The influence of platinum (II) on $\mathrm{TiO}_{2}$ photocatalyzed dye decolourization by rutile, P25 and PC500. J. Photochem. Photobiol. A 2011, 224, 31-37. [CrossRef]

6. Dolat, D.; Ohtani, B.; Mozia, S.; Moszynski, D.; Guskos, N.; Bieluna, Z.L.; Morawski, A.W. Preparation, characterization and charge transfer studies of nickel-Modified and nickel, nitrogen co-modified rutile titanium dioxide for photocatalytic application. Chem. Eng. J. 2014, 239, 149-159. [CrossRef]

7. Dolat, D.; Mozia, S.; Ohtani, B.; Morawski, A.W. Nitrogen, Iron-single modified $\left(\mathrm{N}-\mathrm{TiO}_{2}, \mathrm{Fe}_{-\mathrm{TiO}}\right)$ and co-modified $\left(\mathrm{Fe}, \mathrm{N}-\mathrm{TiO}_{2}\right)$ rutile titanium dioxide as visible-light active photocatalysts. Chem. Eng. J. 2013, 225, 358-364. [CrossRef]

8. Ansari, M.O.; Khan, M.M.; Ansari, S.A.; Raju, K.; Lee, J.; Cho, M.H. Enhanced thermal stability under DC electrical conductivity retention and visible light activity of $\mathrm{Ag} / \mathrm{TiO}_{2} @$ polyaniline nanocomposite film. ACS Appl. Mater. Interfaces 2014, 6, 8124-8133. [CrossRef] [PubMed]

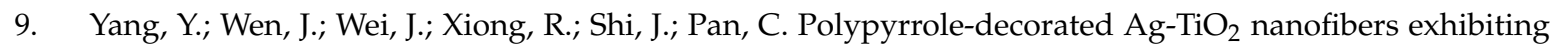
enhanced photocatalytic activity under visible-light illumination. ACS Appl. Mater. Interfaces 2013, 5, 6201-6207. [CrossRef] [PubMed]

10. Wang, X.; Li, S.; Yu, H.; Yu, J.; Liu, S. $\mathrm{Ag}_{2} \mathrm{O}$ as a new visible-light photocatalyst: Self-stability and high photocatalytic activity. Chem. Eur. J. 2011, 17, 7777-7780. [CrossRef] [PubMed]

11. Zhou, W.J.; Leng, Y.H.; Hou, D.M.; Li, H.D.; Li, L.G.; Li, G.Q.; Liu, H.; Chen, S.W. Phase transformation and enhanced photocatalytic activity of S-Doped $\mathrm{Ag}_{2} \mathrm{O} / \mathrm{TiO}_{2}$ heterostructured nanobelts. Nanoscale 2014, 6, 4698-4704. [CrossRef] [PubMed]

12. Duana, F.; Zhanga, Q.; Shi, D.; Chen, M. Enhanced visible light photocatalytic activity of $\mathrm{Bi}_{2} \mathrm{WO}_{6}$ via modification with polypyrrole. Appl. Surf. Sci. 2013, 268, 129-135. [CrossRef]

13. Upadhyay, R.K.; Soin, N.; Roy, S.S. Role of graphene/metal oxide composites as photocatalysts, adsorbents and disinfectants in water treatment. RSC Adv. 2014, 4, 3823-3851. [CrossRef]

14. Deng, F.; Li, Y.; Luo, X.; Yang, L.; Tu, X. Preparation of conductive polypyrrole/ $/ \mathrm{TiO}_{2}$ nanocomposite via surface molecular imprinting technique and its photocatalytic activity under simulated solar light irradiation. Coll. Surf. A 2012, 395, 183-189. [CrossRef]

15. Haspulat, B.; Gülce, A.; Gülce, H. Efficient photocatalytic decolorization of some textile dyes using Fe ions doped polyaniline film on ito coated glass substrate. J. Hazard. Mater. 2013, 260, 518-526. [CrossRef] [PubMed]

16. Zhang, Z.; Yuan, Y.; Liang, L.; Cheng, Y.; Xu, H.; Shi, G.; Jin, L. Preparation and photoelectrochemical properties of a hybrid electrode composed of polypyrrole encapsulated in highly ordered titanium dioxide nanotube Array. Thin Solid Films 2008, 516, 8663-8667. [CrossRef]

17. Tan, Y.; Chen, Y.; Mahimwalla, Z.; Johnson, M.B.; Sharma, T.; Brüning, R.; Ghandi, K. Novel synthesis of rutile titanium dioxide-polypyrrole nano composites and their application in hydrogen generation. Synth. Met. 2014, 189, 77-85. [CrossRef]

18. Gu, S.; Li, B.; Zhao, C.; Xu, Y.; Qian, X.; Chen, G. Preparation and characterization of visible light-driven $\mathrm{AgCl} / \mathrm{PPy}$ photocatalyst. J. Alloys Comp. 2011, 509, 5677-5682. [CrossRef]

19. Wang, B.; Li, C.; Pang, J.; Qing, X.; Zhai, J.; Li, Q. Novel Polypyrrole-Sensitized Hollow $\mathrm{TiO}_{2} / \mathrm{Fly} \mathrm{Ash}$ Cenospheres: Synthesis, characterization, and photocatalytic ability under visible light. Appl. Surf. Sci. 2012, 258, 9989-9996. [CrossRef] 
20. Kandiel, T.A.; Dillert, R.D.; Bahnemann, D.W. Enhanced photocatalytic production of molecular hydrogen on $\mathrm{TiO}_{2}$ modified with Pt-polypyrrole nanocomposites. Photochem. Photobiol. Sci. 2009, 8, 683-690. [CrossRef] [PubMed]

21. Ren, H.T.; Jia, S.Y.; Wu, Y.; Wu, S.H.; Zhang, T.H.; Han, X. Improved photochemical reactivities of $\mathrm{Ag}_{2} \mathrm{O} / \mathrm{gC}_{3} \mathrm{~N}_{4}$ in phenol degradation under UV and visible light. Ind. Eng. Chem. Res. 2014, 53, 17645-17653. [CrossRef]

22. Kowal, K.; Kopaczynska, K.W.K.M.; Dworniczek, E.; Franiczek, R.; Wawrzynska, M.; Vargova, M.; Zahoran, M.; Rakovsky, E.; Kus, P.; Plesch, G.; et al. In-situ photoexcitation of silver-doped titania nanopowders for activity against bacteria and yeasts. J. Colloid Interface Sci. 2011, 362, 50-57. [CrossRef] [PubMed]

23. Liang, N.; Wang, M.; Jin, L.; Huang, S.; Chen, W.; Xu, M.; He, Q.; Zai, J.; Fang, N.; Qian, X. Highly efficient $\mathrm{Ag}_{2} \mathrm{O} / \mathrm{Bi}_{2} \mathrm{O}_{2} \mathrm{CO}_{3}$ p-n heterojunction photocatalysts with improved visible-light responsive activity. ACS Appl. Mater. Interfaces 2014, 6, 11698-11705. [CrossRef] [PubMed]

24. Qiao, Y.; Shen, L.; Wu, M.; Guo, Y.; Meng, Y. A novel chemical synthesis of bowl-shaped polypyrrole particles. Mater. Lett. 2014, 126, 185-188. [CrossRef]

25. Kang, E.T.; Neoh, K.G.; Ong, Y.K.; Tan, K.L.; Tan, B.T.G. XPS studies of proton modification and some anion exchange processes in polypyrrole. Synth. Met. 1990, 30, 69-80. [CrossRef]

26. Landureau, E.P.; Nicolau, Y.F;; Delamar, M. XPS study of layer-by-layer deposited polypyrrole thin films. Synth. Met. 1995, 72, 111-119. [CrossRef]

27. Ansari, M.O.; Yadav, S.K.; Cho, J.W.; Mohammad, F. Thermal stability in terms of DC electrical conductivity retention and the efficacy of mixing technique in the preparation of nanocomposites of graphene/polyaniline over the carbon nanotubes/polyaniline. Compos. Part B 2013, 47, 155-161. [CrossRef]

28. Pérez-Bustamante, R.; Pérez-Bustamante, F.; Estrada-Guel, I.; Santillán-Rodríguez, C.R.; Matutes-Aquino, J.A.; Herrera-Ramírez, J.M.; Miki-Yoshidaa, M.; Martínez-Sánchez, R. Characterization of $\mathrm{Al}_{2024}$-CNTs composites produced by mechanical alloying. Powder Technol. 2011, 212, 390-396. [CrossRef]

29. Zhou, W.; Liu, H.; Wang, J.; Liu, D.; Du, G.; Cui, J. $\mathrm{Ag}_{2} \mathrm{O} / \mathrm{TiO}_{2}$ nanobelts heterostructure with enhanced ultraviolet and visible photocatalytic activity. ACS Appl. Mater. Interfaces 2010, 8, 2385-2392. [CrossRef] [PubMed]

30. Wang, Y.; Liu, L.; Xu, L.; Cao, X.; Li, X.; Huang, Y.; Meng, C.; Wang, Z.; Zhu, W. $\operatorname{Ag}_{2} \mathrm{O} / \mathrm{TiO}_{2} / \mathrm{V}_{2} \mathrm{O}_{5}$ one-dimensional nanoheterostructures for superior solar light photocatalytic activity. Nanoscale 2014, 6, 6790-6797. [CrossRef] [PubMed]

31. Zhang, X.; Bai, R. Surface electric properties of polypyrrole in aqueous solutions. Langmuir 2003, 19, 10703-10709. [CrossRef]

32. Bhaumik, M.; McCrindle, R.; Maity, A. Efficient removal of Congo red from aqueous solutions by adsorption onto interconnected polypyrrole-polyaniline nanofibres. Chem. Eng. J. 2013, 228, 506-515. [CrossRef]

33. Li, J.; Feng, J.; Yan, W. Excellent adsorption and desorption characteristics of polypyrrole/ $\mathrm{TiO}_{2}$ composite for methylene blue. Appl. Surf. Sci. 2013, 279, 400-408. [CrossRef]

34. Moziaa, S.; Morawski, A.W.; Toyoda, M.; Tsumura, T. Effect of process parameters on photodegradation of acid yellow 36 in a hybrid photocatalysis-membrane distillation system. Chem. Eng. J. 2009, 150, 152-159. [CrossRef]

35. Reuterglrdh, L.B.; Iangphasuk, M. Photocatalytic decolourization of reactive azo dye: A comparison between $\mathrm{TiO}_{2}$ and CdS photocatalysis. Chemosphere 1997, 35, 585-596. [CrossRef]

36. Zhang, H.; Zhong, X.; Xu, J.J.; Chen, H.Y. $\mathrm{Fe}_{3} \mathrm{O}_{4} /$ Polypyrrole/Au nanocomposites with core/shell/shell structure: Synthesis, characterization, and their electrochemical properties. Langmuir 2008, 24, 13748-13752. [CrossRef] [PubMed]

37. Sarkar, D.; Ghosh, C.K.; Mukherjee, S.; Chattopadhyay, K.K. Three dimensional $\mathrm{Ag}_{2} \mathrm{O} / \mathrm{TiO}_{2}$ type-II (p-n) nanoheterojunctions for superior photocatalytic activity. ACS Appl. Mater. Interfaces 2013, 5, 331-337. [CrossRef] [PubMed]

(C) 2016 by the authors; licensee MDPI, Basel, Switzerland. This article is an open access article distributed under the terms and conditions of the Creative Commons Attribution (CC-BY) license (http://creativecommons.org/licenses/by/4.0/). 